\title{
Pengaruh Limbah Produksi Pabrik Genteng Sebagai Pengganti Sebagian FlyAsh pada Campuran Beton Terhadap Kuat Tekan Beton
}

\author{
Tri Wardoyo ${ }^{1}$, Boedi Wibowo ${ }^{2}$, Srie Subekti ${ }^{2}$, Triaswati M. N. ${ }^{2}$, Fernao Soares Reis ${ }^{1}$ \\ ${ }^{1}$ Jurusan Teknik Sipil Ubhara, Surabaya \\ ${ }^{2}$ Program Studi Diploma Teknik Sipil FTSP ITS, Surabaya \\ Email: subektisrie@gmail.com
}

\begin{abstract}
The waste of the concrete tile production factory $(L P P G B)$ is the waste obtained from the concrete tile production result at PT. Varia Usaha Beton which is located in Sidoarjo regency. The waste has element $\mathrm{SiO}_{2}$ that reactively reacts with calcium hidroxyde into calcium silicate hydrate, so that it increases the concrete compessive strength. In this research, the waste of the concrete tile production factory is added as a substitute for part/some fly ash in concrete mix. The design of concrete mix composition uses the procedure of the normal concrete mixed design, SNI 03-28341993. The cylinder speciment used has $15 \mathrm{~cm}$ in diameter and $30 \mathrm{~cm}$ in height. The percentages of additional LPPGB in the concrete mix composition are $0 \%, 5 \%, 10 \%$, to $15 \%$ by substituting some of the fly ash. The reseach result indicates that the addition of LPPGB influences the concrete pressure strength; the more the LPPGB content used in concrete mix, the less the concrete pressure strength. For example for K225 concrete strength with the waste proportion of $0 \%$ the 28 days old compressive strength is $350.91 \mathrm{~kg} / \mathrm{cm}^{3}$. However for the same concrete strength with waste composition of $5 \%$, the compressive strength decreases to $296.22 \mathrm{~kg} / \mathrm{cm}^{2}$. This indicates $16 \%$ dcrease of the compressive strength.
\end{abstract}

Keywords: pressure strength, tile factory waste, chemical element.

Abstrak

Limbah pabrik produksi genteng beton (LPPGB) adalah limbah yang didapatkan dari hasil sisa produksi genteng beton di PT. Varia Usaha Beton yang terletak di daerah Sidoarjo. Limbah ini memiliki unsur oksida $\mathrm{SiO}_{2}$ yang reaktif bereaksi dengan kalsium hidroksida menjadi kalsium silikat hidrat sehingga menambah kuat tekan beton. Dalam penelitian ini, Limbah pabrik produksi genteng beton ditambahkan sebagai pengganti sebagian abu terbang (fly ash) pada campuran beton. Desain komposisi campuran beton menggunakan tata cara pembuatan rencana campuran beton normal, SNI 03-2834-1993. Benda uji silinder yang digunakan dengan ukuran diameter $15 \mathrm{~cm}$, dan tinggi $30 \mathrm{~cm}$. Variasi porsentase tambahan LPPGB pada komposisi campuran beton mulai dari $0 \%, 5 \%, 10 \%$, dan $15 \%$ dengan menggantikan sebagian fly ash. Dari hasil penelitian ini menunjukkan bahwa tambahan LPPGB mempunyai pengaruh pada kuat tekan beton, semakin banyak kadar LPPGB yang digunakan dalam campuran beton semakin turun kuat tekan beton. Seperti pada mutu K225 dengan proporsi limbah $0 \%$ (Umur 28 hari) menghasilkan kuat tekan sebesar $350.91 \mathrm{~kg} / \mathrm{cm}^{2}$ dibandingkan dengan komposisi limbah $5 \%$ kuat tekan turun menjadi $296.22 \mathrm{~kg} / \mathrm{cm}^{2}$. Hal ini menunjukkan kuat tekan turun sebesar $16 \%$.

Kata kunci: kuat tekan, limbah pabrik genteng, unsur kimia.

\section{Pendahuluan}

Limbah produksi pabrik genteng (LPPB) merupakan sisa hasil produksi dari pabrik genteng yang tidak di manfaatkan lagi dan dialirkan melalui saluran pembuangan produksi genteng di PT. Varia Usaha Beton yang terletak di daerah Sidoarjo. Berdasarkan Penelitian sebelumnya (Dany Aji Prabowo, 2012) bahwa sifat fisik limbah lumpur berair dan setelah di keringkan berupa butiran halus yang menyerupai pasir,

Jurnal APLIKASI: Media Informasi \& Komunikasi Aplikasi Teknik Sipil Terkini Halaman 31 
lolos ayakan no 200, berwarna putih ke abu-abuan, dan mengandung unsur senyawa kimia $\mathrm{CaCO}_{3}, \mathrm{CaO}$, dan $\mathrm{SiO}_{2}$ (oksida silika).

Beton merupakan bahan bangunan utama yang banyak digunakan dalam suatu struktur bangunan. Beton adalah suatu campuran antara semen, air, dan agregat (bahan pengisi) yang menyebabkan terjadinya suatu hubungan erat antara bahan-bahan tersebut. Beton yang baik mempunyai sifat-sifat kedap terhadap air, awet (tahan lama), tidak retak-retak, dan tahan terhadap cuaca.

Semen Portland adalah bahan konstruksi yang paling banyak dalam pekerjaan beton. Menurut ASTM C-150, 1985, Semen Portland di definisikan sebagai semen hidrolik yang dihasilkan dengan menggiling klinker yang terdiri dari kalsium silikat hidrolik, yang umumnya mengandung satu atau lebih kalsium sulfat sebagai bahan tambahan yang digiling bersama-sama dengan bahan utamanya.

Semen Portland yang digunakan di Indonesia harus memenuhi syarat SII 0013-1981 atau Standar Uji Bahan Bangunan Indonesia 1986, dan harus memenuhi persyaratan yang ditetapkan dalam standar tersebut.

Syarat-syarat air yang dipakai untuk campuran beton harus sesuai dengan ketentuan seperti tertera dalam SK-SNI S-04-1989-F adalah sebagai berikut:

a. Air harus bersih

b. Tidak mengandung lumpur, minyak, dan benda terapung lainnya yang dapat dilihat secara visual. c. Kandungan klorida (CL) tidak lebih dari 500 ppm dan senyawa sulfat tidak lebih dari 1000 ppm sebagai $\mathrm{SO}_{3}$.

d. Bila dibandingkan dengan kekuatan tekan adukan dan beton yang menggunakan air suling, maka kekuatan adukan dan beton yang memakai air yang diperiksa, tidak lebih dari $10 \%$.

e. Semua air meragukan harus Dianalisa secara kimia dan dievaluasi mutunya menurut pemakaiannya (Prabowo, 2012)

Agregat adalah merupakan bahan tambah atau pengisi yang tidak ikut aktif di dalam pengikatan campuran beton. Ukuran maksimum yang lebih kecil pada umumnya akan memberikan kekuatan beton lebih besar. Hal ini karena proses pemecahan, agregat akan cenderung pecah melalui daerah yang lebih lemah, sehingga pengurangan ukuran maksimum agregat berarti memperkecil daerah yang lemah pada agregat. Contoh agregat adalah sebagai berikut:

a. Pasir Lumajang

Agregat ini dapat juga dinamakan dengan pasir sungai, dikarenakan penambangannya dilakukan di daerah sungai, namun ada juga yang dilakukan di pegunungan. Ketersediaan pasir ini berasal dari kegiatan rutin Gunung Semeru yang mengeluarkan material kurang lebih 1 (satu) juta $\mathrm{m}^{3} /$ tahun, berupa muntahan dari Gunung Semeru. Kemudian dibawa oleh air sungai hingga ke laut. Muntahan gunung ini membawa partikel zat besi, sehingga kemudian menjadi pasir besi di tepi pantai. 
b. Limbah Pabrik Genteng

Limbah ini dapat juga disebut sebagai lumpur, karena apabila dilihat secara fisik kering keseluruhan, butirannya seperti debu atau hampir menyerupai abu terbang (fly ash). Limbah ini didapatkan dari hasil produksi genteng berupa lumpur yang bercampur dengan air dan berwarna putih ke abu-abuan. Dalam proses produksi genteng sendiri, dihasilkan limbah sisa rata-rata per hari sebanyak $0,96 \mathrm{~m}^{3}$.

Admixture adalah bahan-bahan yang di tambahkan ke dalam campuran beton pada saat atau selama pencampuran berlangsung. Fungsi dari bahan tambah ini adalah untuk mengubah sifat-sifat dari beton agar lebih menjadi cocok untuk pekerjaan tertentu atau untuk menghemat biaya. Secara umum terdapat dua bahan tambah yang disarankan untuk digunakan dalam pembuatan beton, yaitu bahan tambah yang bersifat kimiawi (Chemical admixture) dan bahan tambah yang bersifat mineral (addictive).

a. Bahan Tambah Kimia (Admixture) Admixture merupakan bahan tambah yang berbentuk cair, namun berfungsi di dalam campuran beton untuk mempercepat proses pengikatan awal semen ataupun memperlambat proses pengikatan awal semen. Tujuan pemakaian Admixture dalam campuran beton adalah untuk meningkatkan (Mulyono, 2004):

- Penampilan (Performance)

- Mutu (Quality)

- Keawetan (Durability)

- Kemudahan pekerjaan (Workability) b. Bahan tambah Mineral (Addictive) Bahan tambah mineral ini merupakan bahan tambah yang dimaksudkan untuk memperbaiki kinerja beton, ataupun dapat digunakan sebagai bahan tambah untuk mengurangi pemakaian jumlah material (Dipohusodo, 1994). Beberapa bahan tambah mineral ini adalah, fly ash, slag, dan silica fume.

Fly ash didefinisikan sebagai butiran halus hasil residu pembakaran batu bara atau bubuk batu bara (ASTM C 618). Fly ash adalah material yang berasal dari sisa pembakaran batu bara yang tidak terpakai. Pembakaran batu bara kebanyakan digunakan pada pembangkit listrik tenaga uap (Kardiyono, 1998). Abu terbang (Fly ash) diperoleh dari hasil residu PLTU. Fly ash dapat dibedakan menjadi 3 jenis, yaitu:

a. Kelas C

Fly ash yang mengandung $\mathrm{CaO}$ di atas $10 \%$ yang dihasilkan dari pembakaran lignite.

b. Kelas F

Fly ash yang mengandung $\mathrm{CaO}$ lebih kecil dari $10 \%$ yang dihasilkan dari pembakaran anthracite.

\section{c. Kelas N}

Pozzolan alam atau hasil pembakaran yang dapat digolongkan antara lain tanah diatomic, opaline, chertz dan shales, tuff dan abu vulkanik.

\subsection{Tujuan}

Tujuan dari penelitian ini adalah untuk mengetahui hasil campuran limbah produksi pabrik genteng (LPPB) sebagai pengganti sebagian fly ash dalam campuran beton. 


\subsection{Perawatan Beton (curing)}

Perawatan beton merupakan prosedur yang digunakan untuk membantu mempercepat proses hidrasi beton, menjaga kestabilan temperatur dan perubahan kelembaban di dalam maupun di luar beton itu sendiri. Secara umum perawatan beton terbagi atas 2 metode, yaitu:

a. Metode perawatan basah

Metode perawatan basah memberikan air yang diperlukan oleh beton. Hal ini menjadikan kondisi beton selama perawatan selalu berhubungan langsung dengan air dalam jangka waktu tertentu, dimulai segera setelah permukaan beton tidak dapat lagi berubah bentuk/rusak.

b. Metode perawatan membran

Metode perawatan membran melindungi air yang ada di dalam beton agar tidak keluar, tanpa menggunakan air tambahan dari luar beton untuk membantu berlangsungnya proses hidrasi. Metode ini disebut metode pengontrol air.

\subsection{Uji Kuat Tekan Beton}

Untuk perhitungan beton pada umur 28 hari, menggunakan perhitungan sebagai berikut:

a. Kuat Tekan Individu

$$
f c i=\frac{P}{A}
$$

b. Kuat Tekan Rata-rata

$$
f c r=\sum_{i=1}^{n} f c i \div n
$$

c. Standar Deviasi

$$
s=\sqrt{\frac{\sum_{i=1}^{n}(f c i-f c r)^{2}}{n-1}}
$$

d. Kuat Tekan Karakteristik

$$
f c^{\prime}=f c r-(1,64 \times s)
$$

dimana:

$\mathrm{P}=$ Beban maksimum $(\mathrm{kg})$

$\mathrm{A}=$ Luas penampang benda uji $\left(\mathrm{cm}^{2}\right)$

$\mathrm{s}=$ Deviasi standar $\left(\mathrm{kg} / \mathrm{cm}^{2}\right)$

$\mathrm{fci}=$ Kuat tekan beton yang didapat dari hasil pengujian $\left(\mathrm{kg} / \mathrm{cm}^{2}\right)$

$\mathrm{fcr}=$ Kuat tekan beton rata-rata $\left(\mathrm{kg} / \mathrm{cm}^{2}\right)$

$\mathrm{n}=$ Jumlah benda uji, minimum 20 buah

$\mathrm{fc}^{\prime}=$ Kuat tekan beton karakteristik $\left(\mathrm{kg} / \mathrm{cm}^{2}\right)$

\section{Metodologi}

Peraturan yang dipakai untuk pemilihan material seperti semen, pasir, agregat harus sesuai SK.SNI.S-04-1989-F, dan bahan tambahan harus memenuhi Spesifikasi bahan tambahan beton SK.SNI.S18-1990-03 dan peraturan lain yang dipakai adalah Metode ASTM (American Standard For Testing Material) dan untuk pelaksanaan penelitian ini dapat dilihat pada diagram alir pelaksanaan penelitian berikut ini.

Peralatan yang digunakan adalah:

a. Timbangan 2600 gram.

b. Satu set alat pemeriksaan uji agregat (cawan, piknometer, oven, mesin ayakan).

c. Satu set ayakan.

d. Agregat kasar dengan ukuran maksimum $40 \mathrm{~mm}$ dari quary mojokerto. 
Tabel 1. Perencanaan/rancangan penelitian

\begin{tabular}{|c|c|c|c|c|c|c|c|}
\hline No & $\begin{array}{l}\text { Benda } \\
\text { Uji }\end{array}$ & $\begin{array}{c}\text { Ukuran } \\
\text { Benda Uji } \\
(\varnothing)\end{array}$ & $\begin{array}{c}\text { Kuat } \\
\text { Tekan } \\
\text { f'c } \\
(\mathrm{Mpa}) \\
\end{array}$ & FAS & $\begin{array}{l}\text { Komposisi Limbah } \\
\text { (L) dan Fly Ash (F) }\end{array}$ & $\begin{array}{l}\text { Umur Beton } \\
\text { (hari) }\end{array}$ & $\begin{array}{l}\text { Jumlah Benda } \\
\text { Uji Tiap Umur }\end{array}$ \\
\hline \multirow{4}{*}{1} & \multirow{12}{*}{ Silender } & \multirow{12}{*}{$\begin{array}{c}\varnothing 15 \times 30 \\
\mathrm{~cm}\end{array}$} & \multirow{4}{*}{22,5} & \multirow{4}{*}{0,64} & L $0 \%-\mathrm{F} 100 \%$ & $7 ; 14 ; 28 ; 56$ & 3 \\
\hline & & & & & L 5\% - F $95 \%$ & $7 ; 14 ; 28 ; 56$ & 3 \\
\hline & & & & & L $10 \%-$ F $90 \%$ & $7 ; 14 ; 28 ; 56$ & 3 \\
\hline & & & & & L $15 \%$ - F $85 \%$ & $7 ; 14 ; 28 ; 56$ & 3 \\
\hline \multirow{4}{*}{2} & & & \multirow{4}{*}{30} & \multirow{4}{*}{0,5} & L $0 \%-F 100 \%$ & $7 ; 14 ; 28 ; 56$ & 3 \\
\hline & & & & & L 5\% - F $95 \%$ & $7 ; 14 ; 28 ; 56$ & 3 \\
\hline & & & & & L $10 \%$ - F $90 \%$ & $7 ; 14 ; 28 ; 56$ & 3 \\
\hline & & & & & L $15 \%-F 85 \%$ & $7 ; 14 ; 28 ; 56$ & 3 \\
\hline \multirow{4}{*}{3} & & & \multirow{4}{*}{50} & \multirow{4}{*}{0,3} & L $0 \%-$ F $100 \%$ & $7 ; 14 ; 28 ; 56$ & 3 \\
\hline & & & & & L 5\% - F $95 \%$ & $7 ; 14 ; 28 ; 56$ & 3 \\
\hline & & & & & L $10 \%$ - F $90 \%$ & $7 ; 14 ; 28 ; 56$ & 3 \\
\hline & & & & & L $15 \%-F 85 \%$ & $7 ; 14 ; 28 ; 56$ & 3 \\
\hline
\end{tabular}

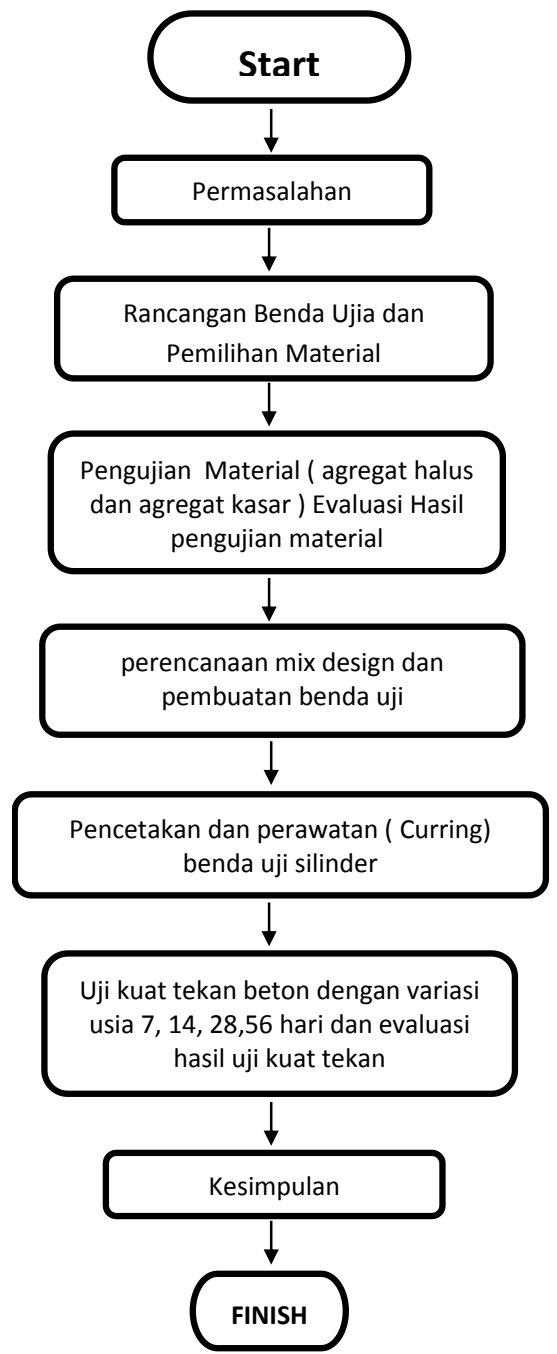

Gambar 1. Diagram Alir Pelaksanaan Pekerjaan e. Satu set kerucut Abrams uji slump.

f. Alat pengaduk molen.

g. Cetakan silinder.

h. Tongkat penumbuk.

i. Satu set alat pelengkap (sekop besar, gelas ukur, ember, cetok, mistar).

j. Takaran silinder volume 3 lt.

Bahan yang digunakan adalah:

a. Agregat halus menggunakan pasir lumajang.

b. Agregat halus tambahan menggunakan limbah produksi genteng beton.

c. Zat addictive tipe D berdasarkan ASTM C 494-92, produksi PT. SIKA Indonesia.

d. Fly ash didapatkan dari PLTU PAITON.

e. Semen Portland Tipe I produksi PT.SEMEN GRESIK.

f. Air bersih dari laboratorium Jaminan Mutu dan Inovasi PT.VARIA USAHA BETON.

Pelaksanaan Penelitian adalah sebagai berikut: 
1. Pemeriksaan uji agregat halus
a. Analisa ayakan pasir
b. Berat jenis pasir
c. Kelembapan pasir
d. Resapan pasir
e. Kebersihan pasir terhadap bahan organik
f. Kebersihan pasir terhadap lumpur
g. Berat volume pasir

2. Pemeriksaan uji agregat kasar
a. Analisa ayakan batu pecah
b. Berat jenis batu pecah
c. Kelembapan batu pecah
d. Resapan batu pecah
e. Kebersihan batu pecah terhadap lumpur
f. Berat volume batu pecah

3. Pemeriksaan uji semen

a. Berat jenis semen

4. Perencanaan Mix Design berdasarkan tata cara perencanaan sesuai dengan standar SK. SNI. 03-28342000. Tata Cara Pembuatan Rencana Campuran Beton Normal. Badan Standarisasi Nasional.

5. Pembuatan benda uji, pengujian slump, berat volume beton, perawatan hingga pengujian dengan uji kuat tekan, dilakukan di laboratorium Jaminan Mutu dan Inovasi PT.VARIA USAHA BETON.

\section{Hasil dan Pembahasan}

Hasil pengujian agregat halus dan agregat kasar dalam penelitian ini dapat dilihat pada Tabel 2 dan Tabel 3. Dari Gambar 1 dapat dilihat hasil uji analisa XRD untuk limbah genteng maka terdapat senyawa sebagai berikut:

1. Calcite, Syn

2. Cristobalite, syn
3. Anorthite, sodian, intermediet

4. Calcium Oxide

Dari Grafik pada Gambar 2 dijelaskan bahwa senyawa yang muncul dengan intensitas tertinggi adalah Calcite, syn $\left(\mathrm{CaCO}_{3}\right)$ sebesar 820, kemudian diikuti senyawa Cristobalite, syn $\left(\mathrm{SiO}_{2}\right)$ dengan intensitas 400 .

\section{- Proporsi Campuran Mix Design}

Berdasarkan hasil perencanaan mix design beton dapat dilihat pada Tabel 4 , Tabel 5 dan Tabel 6.

- Hasil Uji Slump Beton Segar

Didapatkan beberapa hasil uji slump beton segar yang tertera pada Tabel 7 .

- Hasil Uji Berat Volume Beton Segar Didapatkan beberapa hasil uji berat volume beton segar yang tertera pada Tabel 8 dan Gambar 3.

Pada Gambar 3 dapat di jelaskan bahwa untuk mutu K500, kadar limbah yang dapat digunakan adalah $5 \%$ yang memenuhi syarat kuat tekan pada umur 28 dan 56 hari.

- Hasil Uji Kuat Tekan FAS 0,5, Mutu K 300 dapat dlihat pada Gambar 4.

Pada Gamabar 4 dapat dijelaskan bahwa untuk mutu K300, kadar limbah yang dapat di gunakan adalah $5 \%$ seperti terlihat pada umur 14, 28 dan 56 hari.

- Hasil Uji Kuat Tekan Fas 0,64 Mutu K225 dapat dilihat pada Gambar 5.

Pada Gambar 5 dapat dijelaskan bahwa untuk mutu K225, kadar limbah yang dapat di gunakan adalah $5 \%$ seperti terlihat pada umur 7, 14, 28 dan 56 hari dan untuk $10 \%$ pada umur 28 dan 56 hari. 
Tabel 2. Hasil pengujian agregat halus

\begin{tabular}{lccc}
\hline \multicolumn{1}{c}{ Type pengujian } & Agregat halus pasir Lumajang & Standar ASTM & Keterangan \\
& & & \\
\hline Kelembanan & $2,44 \%$ & $1 \%-5 \%$ & OK \\
Berat Jenis & $2,69 \mathrm{gr} / \mathrm{cm}^{3}$ & $1,66-3,3 \mathrm{gr} / \mathrm{cm}^{3}$ & OK \\
Resepan Pasir & $1,11 \%$ & Maximum $4 \%$ & OK \\
Berat Volume (Rojok) & $1,62 \mathrm{gr} / \mathrm{dm}^{3}$ & Maximum $4 \mathrm{gr}^{3} / \mathrm{dm}^{3}$ & OK \\
Berat Volume (Lepas) & $1,28 \mathrm{gr} / \mathrm{dm}^{3}$ & $4 \mathrm{gr} / \mathrm{dm}^{3}$ & OK \\
Kadar Organik & No 1 & Maximum No 6 & OK \\
Kadar Lumpur & $3,45 \%$ & Maximum 5\% & OK \\
Analisa Ayakan & 2,104 & $2,3<\mathrm{FM}>3,1$ & OK \\
\hline
\end{tabular}

Tabel 3. Hasil pengujian agregat kasar

\begin{tabular}{lccccc}
\hline \multicolumn{1}{c}{ Jenis pengujian } & \multicolumn{3}{c}{ Ukuran Kerikil } \\
& $5-10 \mathrm{~mm}$ & $10-20 \mathrm{~mm}$ & $20-30 \mathrm{~mm}$ & Standar ASTM (Max) & Keterangan \\
\hline Kelembanan & $1,13 \%$ & $1,85 \%$ & $1,26 \%$ & Maximum $2 \mathrm{gr} / \mathrm{dm}^{3}$ & OK \\
Berat Jenis & $2,60 \mathrm{gr} / \mathrm{cm}^{3}$ & $2,62 \mathrm{gr} / \mathrm{cm}^{3}$ & $2,68 \mathrm{gr} / \mathrm{cm}^{3}$ & $\begin{array}{c}\text { Maximum } 3,20 \\
\mathrm{gr} / \mathrm{cm}^{3}\end{array}$ & OK \\
Resepan Pasir & $2,35 \%$ & $2,00 \%$ & $2,65 \%$ & Maximum $4 \%$ & OK \\
Berat Volume (Rojok) & $1,595 \mathrm{gr} / \mathrm{dm}^{3}$ & $1,38 \mathrm{gr} / \mathrm{dm}^{3}$ & $1,43 \mathrm{gr} / \mathrm{dm}^{3}$ & $0,4-1,9 \mathrm{gr} / \mathrm{dm}^{3}$ & OK \\
Berat Volume (Lepas) & $1,565 \mathrm{gr} / \mathrm{dm}^{3}$ & $1,20 \mathrm{gr} / \mathrm{dm}^{3}$ & $1,32 \mathrm{gr} / \mathrm{dm}^{3}$ & $0,4-1,9 \mathrm{gr} / \mathrm{dm}^{3}$ & OK \\
Kadar Lumpur & $0,50 \%$ & $0,76 \%$ & $0,62 \%$ & Maximum $1 \%$ & OK \\
Analisa Ayakan & $3,70 \%$ & $3,29 \%$ & $3,62 \%$ & & \\
\hline
\end{tabular}

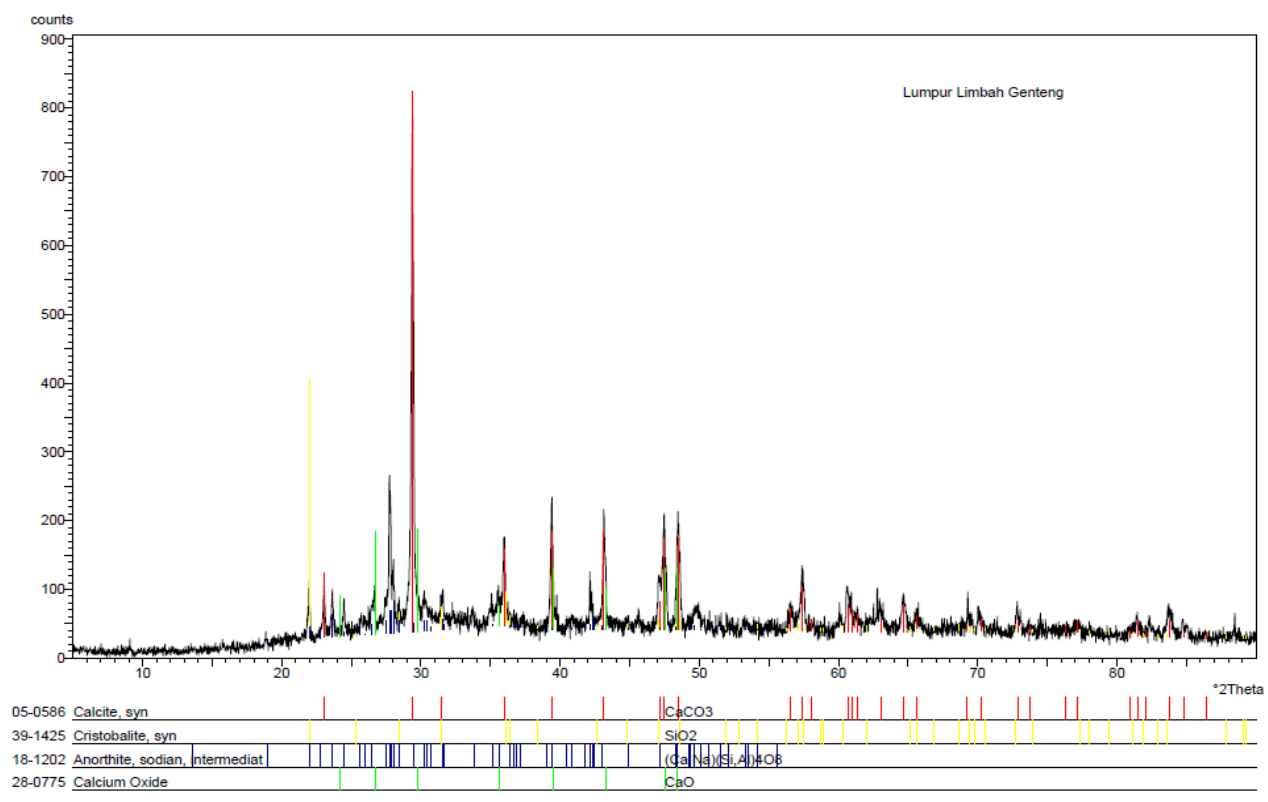

Gambar 2. Hasil Uji Analisa X-RD 
Tabel 4. Hasil mix design FAS 0,3 mutu K 500

\begin{tabular}{|c|c|c|c|c|c|c|c|c|c|}
\hline \multirow{3}{*}{$\begin{array}{c}\text { Komposisi } \\
\text { Material }\end{array}$} & \multicolumn{8}{|c|}{ Kadar Limbah } & \multirow{3}{*}{ Satuan } \\
\hline & \multicolumn{2}{|c|}{$0 \%$} & \multicolumn{2}{|c|}{$5 \%$} & \multicolumn{2}{|c|}{$10 \%$} & \multicolumn{2}{|c|}{$15 \%$} & \\
\hline & $1 \mathrm{~m}^{3}$ & $0,06 \mathrm{~m}^{3}$ & $1 \mathrm{~m}^{3}$ & $0,06 \mathrm{~m}^{3}$ & $1 \mathrm{~m}^{3}$ & $0,06 \mathrm{~m}^{3}$ & $1 \mathrm{~m}^{3}$ & $0,06 \mathrm{~m}^{3}$ & \\
\hline Air & 191 & 11,46 & 191 & 11,46 & 191 & 11,46 & 191 & 11,46 & lt \\
\hline $\begin{array}{l}\text { Agregat } \\
\text { halus }\end{array}$ & 685 & 41,1 & 685 & 41,1 & 685 & 41,1 & 685 & 41,1 & $\mathrm{~kg}$ \\
\hline $\begin{array}{l}\text { Total } \\
\text { agregat } \\
\text { kasar }\end{array}$ & 837,23 & 50,23 & 837,23 & 50,23 & 837,23 & 50,23 & 837,23 & 50,23 & $\mathrm{~kg}$ \\
\hline $\begin{array}{l}\text { Agregat 5- } \\
10\end{array}$ & 42 & 2,52 & 42 & 2,52 & 41,86 & 2,51 & 41,86 & 2,51 & $\mathrm{~kg}$ \\
\hline $\begin{array}{l}\text { Agregat 10- } \\
20\end{array}$ & 251 & 15,06 & 251 & 15,06 & 251 & 15,06 & 251 & 15,06 & $\mathrm{~kg}$ \\
\hline $\begin{array}{l}\text { Agregat 20- } \\
30\end{array}$ & 544 & 32,65 & 544 & 32,65 & 544 & 32,65 & 544 & 32,65 & $\mathrm{~kg}$ \\
\hline Limbah & 0 & 0 & 7,95 & 0,477 & 15,9 & 0,95 & 23,85 & 1,43 & $\mathrm{~kg}$ \\
\hline Sika Type D & 2 & 0,12 & 1,97 & 0,12 & 1,95 & 0,12 & 1,93 & 0,12 & lt \\
\hline Fly Ash & 159 & 9,54 & 151,05 & 9,06 & 143,1 & 8,59 & 135,15 & 8,11 & $\mathrm{~kg}$ \\
\hline Semen & 636 & 38,16 & 636 & 38,16 & 636 & 38,16 & 636 & 38,16 & $\mathrm{~kg}$ \\
\hline
\end{tabular}

Tabel 5. Hasil mix design FAS 0,5 mutu K 300

\begin{tabular}{|c|c|c|c|c|c|c|c|c|c|}
\hline \multicolumn{10}{|c|}{ Kadar Limbah } \\
\hline \multirow{2}{*}{$\begin{array}{c}\text { Komposisi } \\
\text { Material }\end{array}$} & \multicolumn{2}{|c|}{$0 \%$} & \multicolumn{2}{|c|}{$5 \%$} & \multicolumn{2}{|c|}{$10 \%$} & \multicolumn{2}{|c|}{$15 \%$} & \multirow[t]{2}{*}{ Satuan } \\
\hline & $1 \mathrm{~m}^{3}$ & $0,06 \mathrm{~m}^{3}$ & $1 \mathrm{~m}^{3}$ & $0,06 \mathrm{~m}^{3}$ & $1 \mathrm{~m}^{3}$ & $0,06 \mathrm{~m}^{3}$ & $1 \mathrm{~m}^{3}$ & $0,06 \mathrm{~m}^{3}$ & \\
\hline Air & 191 & 11,46 & 191 & 11,46 & 191 & 11,46 & 191 & 11,46 & lt \\
\hline $\begin{array}{l}\text { Agregat } \\
\text { halus }\end{array}$ & 799,5 & 47,98 & 799,65 & 47,98 & 799,65 & 47,98 & 799,35 & 47,98 & $\mathrm{~kg}$ \\
\hline $\begin{array}{l}\text { Total } \\
\text { agregat } \\
\text { kasar }\end{array}$ & 977,35 & 58,64 & 977,65 & 58,64 & 977,35 & 58,64 & 977,35 & 58,64 & $\mathrm{~kg}$ \\
\hline $\begin{array}{l}\text { Agregat 5- } \\
10\end{array}$ & 48,87 & 2,93 & 48,87 & 2,93 & 48,87 & 2,93 & 48,87 & 2,93 & $\mathrm{~kg}$ \\
\hline $\begin{array}{l}\text { Agregat 10- } \\
20\end{array}$ & 293,21 & 17,59 & 293,21 & 17,59 & 293,21 & 17,59 & 293,21 & 17,59 & $\mathrm{~kg}$ \\
\hline $\begin{array}{l}\text { Agregat 20- } \\
30\end{array}$ & 635,28 & 38,12 & 635,28 & 38,12 & 635,28 & 38,12 & 635,28 & 38,12 & $\mathrm{~kg}$ \\
\hline Limbah & 0 & 0 & 4,78 & 0,29 & 9,5 & 0,57 & 14,33 & 0,86 & $\mathrm{~kg}$ \\
\hline Sika Type D & 1,19 & 0,07 & 0,95 & 0,06 & 0,94 & 0,06 & 0,93 & 0,06 & lt \\
\hline Fly Ash & 95,5 & 5,73 & 90,73 & 5,44 & 85,95 & 5,16 & 81,18 & 4,87 & $\mathrm{~kg}$ \\
\hline Semen & 382 & 22,92 & 382 & 22,92 & 382 & 22,92 & 382 & 22,92 & $\mathrm{~kg}$ \\
\hline
\end{tabular}

\section{Simpulan}

1. Proporsi kadar limbah yang dapat di gunakan sebagai pengganti sebagian bahan campuran beton adalah kadar limbah dengan proporsi campuran sebesar $5 \%$ karena memenuhi kriteria kuat tekan yang telah di tentukan yaitu K500, K300 dan K225.

2. Untuk kadar limbah dengan proporsi campuran sebesar $10 \%$ dapat di gunakan untuk mutu K225 dan K300. 
Tabel 6. Hasil mix design FAS 0,64 mutu K 225

\begin{tabular}{|c|c|c|c|c|c|c|c|c|c|}
\hline \multirow{3}{*}{$\begin{array}{c}\text { Komposisi } \\
\text { Material }\end{array}$} & \multicolumn{8}{|c|}{ Kadar Limbah } & \multirow{3}{*}{ Satuan } \\
\hline & \multicolumn{2}{|c|}{$0 \%$} & \multicolumn{2}{|c|}{$5 \%$} & \multicolumn{2}{|c|}{$10 \%$} & \multicolumn{2}{|c|}{$15 \%$} & \\
\hline & $1 \mathrm{~m}^{3}$ & $0,06 \mathrm{~m}^{3}$ & $1 \mathrm{~m}^{3}$ & $0,06 \mathrm{~m}^{3}$ & $1 \mathrm{~m}^{3}$ & $0,06 \mathrm{~m}^{3}$ & $1 \mathrm{~m}^{3}$ & $0,06 \mathrm{~m}^{3}$ & \\
\hline Air & 191 & 11,46 & 191 & 11,46 & 191 & 11,46 & 191 & 11,46 & lt \\
\hline $\begin{array}{l}\text { Agregat } \\
\text { halus }\end{array}$ & 837 & 50,22 & 837 & 50,22 & 837 & 50,22 & 837 & 50,22 & $\mathrm{~kg}$ \\
\hline $\begin{array}{l}\text { Total } \\
\text { agregat } \\
\text { kasar }\end{array}$ & 1023 & 61,38 & 1023 & 61,38 & 1023 & 61,38 & 1023 & 61,38 & $\mathrm{~kg}$ \\
\hline $\begin{array}{l}\text { Agregat 5- } \\
10\end{array}$ & 51 & 3,06 & 51 & 3,06 & 51 & 3,06 & 51 & 3,06 & $\mathrm{~kg}$ \\
\hline $\begin{array}{l}\text { Agregat 10- } \\
20\end{array}$ & 307 & 18,42 & 307 & 18,42 & 307 & 18,42 & 307 & 18,42 & $\mathrm{~kg}$ \\
\hline $\begin{array}{l}\text { Agregat 20- } \\
30\end{array}$ & 665 & 39,9 & 665 & 39,9 & 665 & 39,9 & 665 & 39,9 & $\mathrm{~kg}$ \\
\hline Limbah & 0 & 0 & 3,73 & 0,22 & 7,45 & 0,45 & 11,18 & 0,68 & $\mathrm{~kg}$ \\
\hline Sika Type D & 0,75 & 0,05 & 0,74 & 0,04 & 0,73 & 0,04 & 0,72 & 0,04 & lt \\
\hline Fly Ash & 74,5 & 4,47 & 70,78 & 4,25 & 67 & 4,02 & 63,33 & 3,8 & $\mathrm{~kg}$ \\
\hline Semen & 289 & 17,34 & 289 & 17,34 & 289 & 17,34 & 289 & 17,34 & $\mathrm{~kg}$ \\
\hline
\end{tabular}

Tabel 7. Hasil Uji Slump

\begin{tabular}{|c|c|c|c|c|c|c|}
\hline $\begin{array}{l}\text { Mutu } \\
\text { Beton }\end{array}$ & $\begin{array}{l}\text { Faktor } \\
\text { Air } \\
\text { Semen }\end{array}$ & $\begin{array}{l}\text { Fly Ash (F) \% - } \\
\text { Limbah (L) \% }\end{array}$ & $\begin{array}{c}\text { Ketinggian } \\
\text { awal }(\mathrm{cm}) \\
\text { a }\end{array}$ & $\begin{array}{c}\text { Ketinggian } \\
\text { Kedua }(\mathrm{cm}) \\
\text { b }\end{array}$ & $\begin{array}{c}\text { Ketinggian } \\
\text { Ketiga }(\mathrm{cm}) \\
\text { c }\end{array}$ & $\begin{array}{l}\text { Test Slump } \\
\quad(\mathrm{cm}) \\
(\mathrm{a}+\mathrm{b}+\mathrm{c}) / 3\end{array}$ \\
\hline \multirow{4}{*}{ K225 } & \multirow{4}{*}{0,64} & F $100 \%$ - L $0 \%$ & 12,50 & 12,00 & 11,60 & 12,03 \\
\hline & & F $95 \%-\mathrm{L} 5 \%$ & 11,70 & 12,00 & 12,30 & 12,00 \\
\hline & & F $90 \%-\mathrm{L} 10 \%$ & 11,40 & 12,30 & 12,30 & 12,00 \\
\hline & & F $85 \%$ - L $15 \%$ & 12,80 & 10,70 & 12,60 & 12,03 \\
\hline \multirow{4}{*}{ K300 } & \multirow{4}{*}{0,5} & F $100 \%-\mathrm{L} 0 \%$ & 11,80 & 12,20 & 12,00 & 12,00 \\
\hline & & F $95 \%-\mathrm{L} 5 \%$ & 11,00 & 12,20 & 13,00 & 12,07 \\
\hline & & F $90 \%$ - L $10 \%$ & 12,50 & 12,00 & 11,60 & 12,03 \\
\hline & & F $85 \%-$ L $15 \%$ & 12,10 & 11,50 & 12,30 & 11,97 \\
\hline \multirow{4}{*}{ K500 } & \multirow{4}{*}{0,3} & F $100 \%$ - L $0 \%$ & 12,00 & 11,50 & 12,00 & 11,83 \\
\hline & & F 95\% - L 5\% & 12,10 & 11,60 & 10,50 & 11,40 \\
\hline & & F $90 \%$ - L $10 \%$ & 11,30 & 12,50 & 11,60 & 11,80 \\
\hline & & F $85 \%$ - L $15 \%$ & 12,50 & 10,00 & 13,00 & 11,83 \\
\hline
\end{tabular}

Jadi, limbah produksi pabrik genteng beton ini dapat di gunakan sebagai pengganti sebagian bahan campuran beton yaitu abu terbang (Fly Ash) dengan proporsi $5 \%$ dan bisa juga $10 \%$ dari total kebutuhan fly ash. Limbah pabrik produksi genteng beton dapat di gunakan untuk pengganti sebagian fly ash dalam campuran beton untuk beton mutu rendah seperti K225 dan beton mutu sedang seperti K300. 
Tabel 8. Hasil Test Berat Volume Beton Segar

\begin{tabular}{ccccccc}
\hline $\begin{array}{c}\text { Mutu } \\
\text { Beton }\end{array}$ & $\begin{array}{c}\text { Faktor Air } \\
\text { Semen }\end{array}$ & $\begin{array}{c}\text { Fly Ash (F) \% - Limbah } \\
\text { (L) \% }\end{array}$ & W2 (gr) & W1 (gr) & V (m $\left.{ }^{3}\right)$ & $\begin{array}{c}\text { Volume } \\
\text { Beton segar } \\
\left(\mathrm{gr} / \mathrm{m}^{3}\right)\end{array}$ \\
\hline \multirow{3}{*}{ K225 } & \multirow{3}{*}{0,64} & F 100\% - L 0\% & 12887 & 4347 & 3000 & 2,847 \\
& & F 95\% - L 5\% & 12870 & 4347 & 3000 & 2,841 \\
& & F 90\% - L 10\% & 12862 & 4347 & 3000 & 2,838 \\
& F 85\% - L 15\% & 12850 & 4347 & 3000 & 2,840 \\
\hline \multirow{3}{*}{ K300 } & \multirow{3}{*}{0,5} & F 100\% - L 0\% & 12788 & 4347 & 3000 & 2,814 \\
& & F 95\% - L 5\% & 12784 & 4347 & 3000 & 2,812 \\
& & F 90\% - L 10\% & 12772 & 4347 & 3000 & 2,808 \\
& & F 85\% - L 15\% & 12765 & 4347 & 3000 & 2,806 \\
\hline \multirow{3}{*}{ K500 } & \multirow{3}{*}{0,3} & F 100\% - L 0\% & 12700 & 4347 & 3000 & 2,784 \\
& & F 95\% - L 5\% & 12688 & 4347 & 3000 & 2,780 \\
& & F 90\% - L 10\% & 12650 & 4347 & 3000 & 2,768 \\
& & F 85\% - L 15\% & 12646 & 4347 & 3000 & 2,766 \\
\hline
\end{tabular}

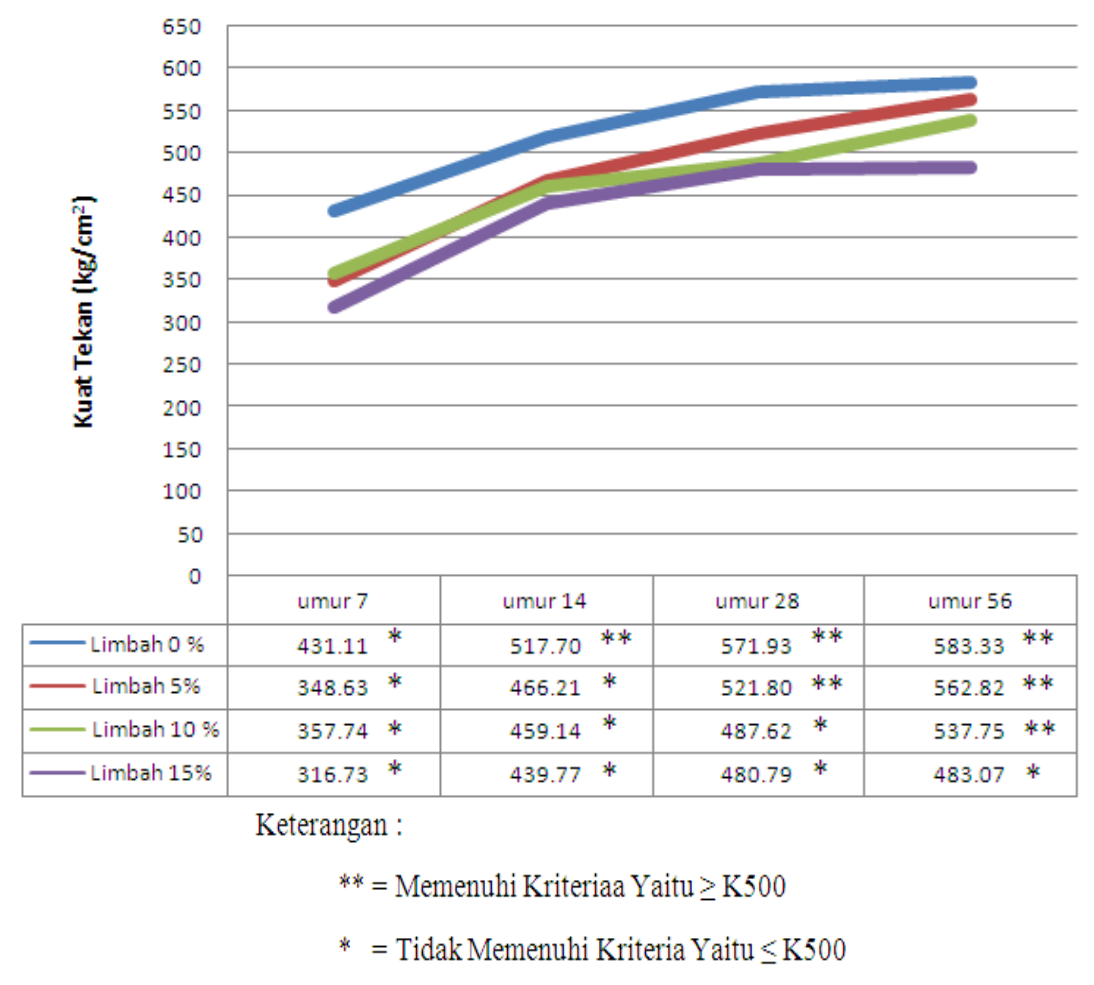

Gambar 3. Grafik Uji Kuat Tekan Mutu K500 Umur 7 - 56 Hari

\section{Daftar Pustaka}

ASTM. (American Standard for Testing Material) Standart Test method for making, accelerated Curing, and Testing Compression Test Specimen - ASTM.684, Annual
Books of ASTM Standard 1995 Concretes and Aggregates, VOl.04.02 Construction

Danny Aji Prabowo, (2012), Studi Efek Penambahan Limbah Produksi PabrikGenteng Pada Campuran 
Beton Dengan Rasio Terhadap Agregat.

Dipohusodo, (1994) Hubungan Antara

Faktor Air Semen Terhadap Kekuatan Teka Beton.

Kardiyono, (1998) Pengaruh jumlah semen terhadap kuat tekan beton pada faktor air semen sama.

Mulyono, (2004), Teknologi Beton. Yogyakarta: Andi.

Praktikum Teknologi Beton. Petunjuk Praktikum Teknologi Beton.

PT. Varia Usaha Beton Laboratorium Jaminan Mutu dan Inovasi

Pujo Aji, Rachmat Purwono, P-U HAKI, Pengendalian Mutu Beton Technical Data Sheet. Edition 3, (2009), Plastiment - VZ, Water Reducing and Set Retarding, <URL:http://www.sika.co.id $>$.

Sebayang, Surya, (2006), Pengaruh Abu Terbang Sebagai Pengganti Sejumlah Semen Type V Pada Beton Mutu Tinggi, Teknik Sipil. Vol. 6. No. 2. Lampung April, 2006. Pp. 116-123.

SK. SNI. T-15-1990-2003. Tata Cara Rancangan Campuran Beton Normal.

SK-SNI S-04-1989-F, Syarat - syarat air.

SII - 0052 - 80, Syarat mutu agregat halus dan Kasar.

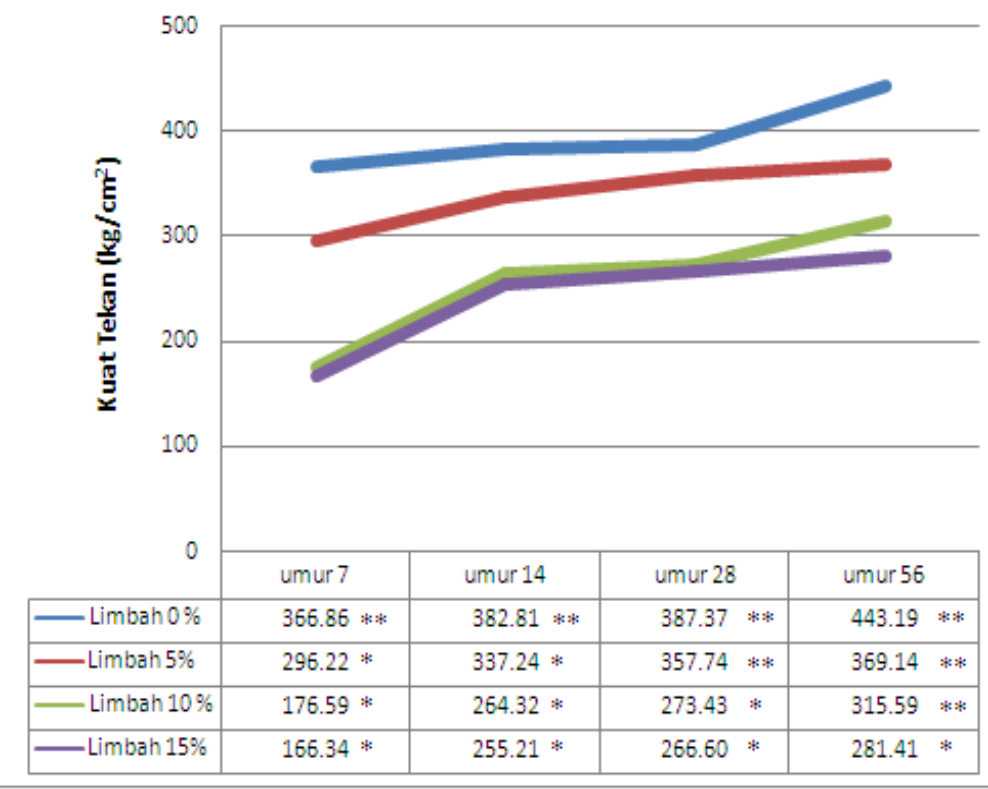

Keterangan

$* *=$ Memenuhi Kriteriaa Yaitu $\geq \mathrm{K} 300$

* = Tidak Memenuhi Kriteria Yaitu $\leq \mathrm{K} 300$

Gambar 4. Grafik Uji Kuat Tekan Mutu K300 Umur 7 - 56 Hari 


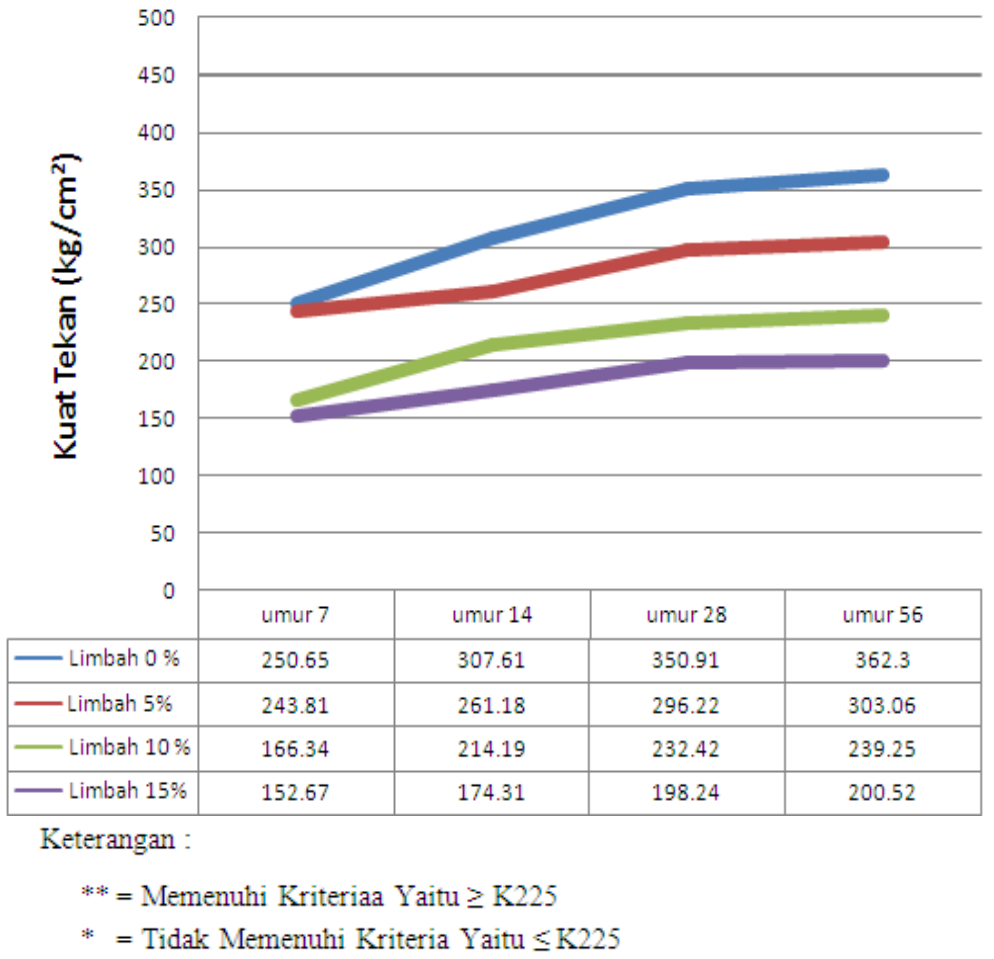

Gambar 5. Grafik Uji Kuat Tekan FAS 0,64 K225 Umur 7 - 56 Hari 